\title{
МЮНХЕНСКИЙ СГОВОР: ЗАКУЛИСНАЯ ИСТОРИЯ
}

\author{
А.Ю. Борисов
}

Московский государственный институт международных отношений (университет) МИД России

В фокусе статьи - связь Мюнхенского сговора и его драматических последствий с процессами распада межвоенного мира на основе Версальско-Вашингтонской системы, нарушения общеевропейского равновесия и вызревания предвоенного политического кризиса.

Трагическая судьба Чехословакии учит, что предательство национальной элитой интересов своей страны, передача государства под «внешнее управление» оборачивается в конечном счёте и национальным самоубийством для правящей элитой, и потерей ею своего привилегированного положения.

В статье предпринята попытка увязать трагическое историческое прошлое Чехословакии, расплатившейся за свой отказ от суверенитета в результате политики национальной элиты, с сегодняшним политическим дискурсом вокруг вопросов глобализации и национальных интересов, влияния внешних сил на политику зависимых и не самостоятельных государств и нередко негативных последствий этого влияния.

Многое и сегодня в политике ведущих западных держав, прежде всего Соединённых Штатов, перекликается с их действиями в период подготовки и осуществления Мюнхенского сговора. Игра на международных противоречиях, попытки подставить под удар противника, а самому остаться в стороне, выдать жертву агрессору и т.д. опасны как вчера, так и сегодня и чреваты серьёзными международными последствиями для их организаторов и вдохновителей.

В отличие от многочисленных работ на данную тему, увидевших свет в нашей стране и за рубежом, и сосредоточивших главное внимание на деятельности европейских «умиротворителей»- англичан и французов, автор статьи показывает скрытую от глаз роль американской дипломатии в решении судьбы Чехословакии. Тогда во главе США находился такой крупный политический деятель, как президент Франклин Рузвельт - признанный мастер игры на международных противоречиях, избегавший быть на авансцене мировой политики в сомнительных вопросах.

Для уяснения роли США в европейской политике в период Мюнхенского кризиса в статье привлечены оригинальные источники из архива американского посла в Советском Союзе Дж. Дэвиса, хранящиеся в Библиотеке Конгресса США и проливающие дополнительный свет на перипетии европейской политики в то бурное время и малоизвестные стороны сталинской дипломатии в период борьбы за коллективную безопасность.

Ключевые слова: США, Рузвельт, национальный интерес, Мюнхенский сговор, дипломатия, Вторая мировая война.

Удк 93/94

Поступила в редакцию 28.02.2017 г.

Принята к публикации 04.06.2017 г. 

ема национальных интересов, оказавшаяся немодной в век «сплошной» глобализации, неожиданно вновь оказалась в центре общественного дискурса в связи с затяжным кризисом всего либерального мегапроекта Запада. «Конец истории», наивно преподнесенный Ф. Фукуямой как торжество американоцентричного мира, обернулось лишь очередной сменой мировых противоречий, болезненным переходом к новому, полицентричному миропорядку. «Век национализма» - так в специальной статье ещё в 2013 г. анонсировал суть наступающей эпохи влиятельный американский журнал The National Interest [13].

Между тем история учит, что забвение национальных интересов под давлением внешних обстоятельств или в результате корыстных расчётов «своей» правящей элиты не только оборачивается трагедией для народа данной страны, но может иметь и далеко идущие международные последствия. В длинной цепи событий, подтолкнувших мир ко Второй мировой войне (1939-1945 гг.), особое место занимает Мюнхенская конференция 1938 г., вошедшая в историю как преступный сговор Великобритании, Франции, нацистской Германии и фашистской Италии с целью «мирной» выдачи Гитлеру Чехословакии.

По сути дела, Мюнхенский сговор, от которого решительно отмежевался СССР, явился пиком, проводимой западными державами политики «умиротворения» агрессоров и обозначил «точку невозврата» в переходе от мира к войне. Его логическим следствием стали двусторонние соглашения, подписанные Англией, Францией и, много позже других, Советским Союзом с гитлеровской Германией, чтобы отвести угрозу агрессии от себя. Получилось так, что эгоистический интерес, возведенный в ранг государственной политики западными демократиями, одержал верх над коллективной ответственностью. Когда предвоенные годы стали уже далекой историей, глава Советского правительства И.В. Сталин в перерыве между заседаниями Ялтинской конференции (февраль 1945 г.) лаконично скажет президенту США Ф. Рузвельту, что если бы не было Мюнхенского сговора, то не было бы и советско-германского пакта о ненападении ${ }^{1}$. Президент не найдет, что ответить. Тем более, что США формально остались в стороне от «грязной сделки».

В исторической литературе, как в отечественной, так и в зарубежной, давно расставлены все основные акценты и выявлены главные виновники и пособники постыдного сговора, его жертвы и их защитники. Имена английского премьера Н. Чемберлена, французского премьера Э. Даладье, не говоря уже о кровавых диктаторах Гитлере и Муссолини, занесены в книгу памяти в качестве больших и малых злодеев. Но остается ещё большое историческое закулисье, выявление роли тех, кто не был на авансцене, но кто реально определял хитросплетения европейской политики и вполне мог воспротивиться неблагоприятному сценарию, но не захотел этого сделать. Речь идёт о предвоенной дипло-

\footnotetext{
1 Foreign Relations of the United States. Diplomatic Papers. The Conferences at Malta and Yalta. Washington: U.S. Government Printing Office, 1955. P. 367.
} 
матии Соединённых Штатов, нити которой крепко держал в своих руках такой крупный государственный деятель, большой мастер политических интриг и игры на противоречиях, каким был президент Рузвельт. Не случайно в близком кругу его сравнивали с «львом и лисицей» в одном лице.

В отечественной литературе, как советского, так и постсоветского периода, в какой-то мере под влиянием американских исследований и, разумеется, роли Рузвельта как одного из руководителей антигитлеровской коалиции и по контрасту с его преемником сложился несколько идеализированный образ американского президента, присутствующий и в сегодняшних российских политических оценках. Бесспорно, в критический момент мировой истории Рузвельт оказался на высоте положения и, отбросив идеологическую предвзятость, проявил политическую мудрость, заключив вместе с Великобританией военный союз с СССР. Но в довоенные годы, когда решался вопрос быть или не быть мировой войне, США, несмотря на всё показное миролюбие Белого дома, сознательно попустительствовали державам-агрессорам - Германии, Италии и Японии и не мешали им творить произвол и беззаконие, рассчитывая остаться в стороне от военного конфликта к своей выгоде. Как иронически замечал тогда У. Черчилль, «Америка ни во что не вмешивалась и лишь всем желала добра». Идейной подоплекой этой стратегии являлся американский изоляционизм или так называемое невмешательство в мировые дела, временами дополнявшие политику активного интервенционизма.

Известное представление о внутренних пружинах американской политики в то судьбоносное для мира время дают ранее не публиковавшиеся материалы из архива крупного американского бизнесмена, друга президента Рузвельта, щедро финансировавшего его предвыборные каомпании, Джозефа Дэвиса, назначенного в конце 1936 г. американским послом США в Советском Союзе. В отличие от своего предшественника, пронацистски настроенного Уильяма Буллита, Дэвису удалось установить доверительные отношения с Кремлём. Известно, что Сталин отвечал ему взаимностью и считал, что «с ним можно иметь дело». Перед послом была поставлена конкретная задача «выяснения военной и экономической мощи русских» и ответа на вопрос, весьма волновавший Рузвельта, «на чьей стороне они будут в случае войны»².

В то довоенное время в Москве ещё испытывали определённые иллюзии в отношении политики США и надеялись, что в Вашингтоне сумеют трезво оценить опасность, исходящую от блока агрессоров и важность сотрудничества с Москвой. Тем более что на том этапе главные угрозы для СССР исходили из Европы и Дальнего Востока, а США, какое-то время, пока окончательно не раскрылось своекорыстие их политики, рассматривались в роли потенциального партнёра, если и не союзника, особенно в дальневосточных делах. Между тем

\footnotetext{
2 Library of Congress. Manuscript Division, Joseph T. Davies. Chronological File, 1936 - 1938. Con. 5. Diary June 1, 1937 (далее - Library of Congress, Joseph T. Davies. Chronological File).
} 
для Вашингтона, отдалённого от основных центров конфликтов гладью двух океанов, мир был большой шахматной доской, где принципиальное значение имела расстановка основных фигур, особенно, когда речь зашла о судьбе Чехословакии.

Во времена Мюнхена Дэвис через голову реакционеров из Госдепартамента будет выполнять ответственные поручения Рузвельта в европейских столицах, выступая в роли «честного маклера», до конца, вероятно, не проникая во все тонкости, если не сказать коварство, дипломатической тактики своего шефа. Когда сталинская игра с Гитлером потерпит фиаско и Германия в нарушение Пакта о ненападении всей своей мощью обрушится на Советский Союз, Дэвис окажется едва ли не единственным среди правительственных чиновников-маловеров в Вашингтоне, кто пророчески публично заявит, что "русские ещё изумят мир».

Едва заступив на свой дипломатический пост, Дэвис 9 марта 1937 г. сообщает пресс-секретарю Белого дома Стиву Эрли: «Нельзя не отдавать себе отчёт в том, что здесь вызревают силы, с которыми будущему придется считаться. При условии мира они достигнут крупных экономических успехов. Но о мире можно разве только мечтать. Германия и Япония - постоянная угроза». 1 июня после кратковременного посещения Лондона и встреч с английскими политическими деятелями Дэвис записал в своём дневнике: «Всё, что я рассказал им об увиденном (в СССР - А.Б.), поразило их воображение, но я всё же мог видеть, с каким недоверием они относились к мощи России при Советах» ${ }^{3}$.

Информация посла Дэвиса противоречила устоявшимся в западных столицах взглядам о «слабости СССР», подорванного массовыми репрессиями и «чистками» Красной Армии, его стремлении к «экспорту революции» и т.д., что складывалось в миф о «колоссе на глиняных ногах» и опасности сотрудничества с ним Запада. Именно поэтому Советское правительство, видя в Дэвисе доброжелателя, создало для американского посла, вопреки традиционной «закрытости» режима для иностранцев, привилегированные условия. В дипломатическом корпусе он был на особом положении, часто встречался с советскими руководителями и получал из первых рук интересующую его информацию. Ему разрешили совершить ряд ознакомительных поездок по крупнейшим промышленным центрам, включая новые индустриальные гиганты в Сибири и на Урале.

Следуя указаниям президента, Дэвис особое внимание уделял изучению потенциальных возможностей СССР на случай большой войны. 10 июля 1937 г. он сообщает помощнику президента Марвину Макинтайру: «Англия и Франция преуменьшают военную мощь этого правительства, а Гитлер - нет». В конце июля посол подготовил для президента обстоятельный документ под названием «Важность промышленности для обороны», в котором отмечал: «Европейские военные наблюдатели неофициально признают, что [Красная]

\footnotetext{
${ }^{3}$ Library of Congress. Manuscript Division, Joseph T. Davies. Chronological File, 1936 - 1938. Con. 5. Diary June 1, 1937 (далеe - Library of Congress, Joseph T. Davies. Chronological File).
} 
Армия является первоклассной с точки зрения рядового и командного состава. Советская промышленность, судя по тому, что я увидел, поразит Запад в случае войны». 28 июля он информирует государственного секретаря Корделла Хэлла об арестах в армии и вопреки волне поднявшихся слухов о «шаткости» режима Советов сообщает, что «положение этого правительства и стоящего у власти режима выглядит неприступным в настоящее время и, вероятно, на обозримое будущее» ${ }^{4}$.

Дэвис одним из немногих на Западе достаточно трезво оценивал и советскую внешнюю политику в тот кризисный период. В 30-е гг. прошлого века, особенно после прихода Гитлера к власти в Германии, в Кремле думали уже не о том, как разжечь революционный пожар на Западе, а как не оказаться в полной изоляции перед лицом единого фронта капиталистических держав. А к этому неизбежно вела политика «умиротворения» агрессоров, главным инициатором которой выступал «туманный Альбион», объединивший традиционный имперский антирусский синдром с новой классовой враждебностью к большевикам, при некоторой непоследовательности и колебаниях Парижа и скрытой поддержки со стороны американцев. Линии на «умиротворение» агрессоров советская дипломатия попыталась противопоставить идею коллективной безопасности с опорой на механизм Лиги Наций, что в Кремле рассматривали, как попытку использовать межимпериалистические противоречия в духе ленинского учения. Борьба этих двух тенденций в европейской и мировой политике достигла своего апогея во время мюнхенского кризиса.

Все это не из-за океана, а с близкого расстояния наблюдал посол Дэвис, постепенно теряя присущий ему оптимизм. 1 сентября 1937 г. в рубрике «Европейская ситуация по отношению к России» он записывает в журнале посла свои мысли: «Германия - эпицентр бури. Замыслам Германии отвечает изображать коммунизм в качестве советской угрозы для цивилизации. Россия, по моему мнению, является искренним поборником мира». Из этих размышлений за рабочим столом посла рождались телеграммы в Вашингтон. 3 ноября он сообщает Хэллу: «Советский Союз уже является действенным фактором международного мира, значение которого неуклонно нарастает» ${ }^{5}$

При этом Дэвиса едва ли можно было считать идеалистом, попавшимся на крючок сталинской пропаганды. Ситуацию в СССР он видел во всей её сложности и трагизме, оказавшись в Москве на пике массовых репрессий, когда в одном только 1937 г., согласно докладной записке КГБ, подготовленной по указанию Н.С. Хрущёва для его известного «антисталинского» секретного доклада перед делегатами ХХ съезда КПСС в феврале 1956 г., было репрессировано 918671 чел., из которых 353074 было расстреляно [3, с. 463].

\footnotetext{
4 Library of Congress. Manuscript Division, Joseph T. Davies. Chronological File, 1936 - 1938. J. Davies Journal, July 28, 1937.

5 Library of Congress. Manuscript Division, Joseph T. Davies. Chronological File, 1936 - 1938. J. Davies Journal, November, $2-7,1937$.
} 
Можно только поражаться способности Дэвиса не поддаваться доминировавшим тогда в Вашингтоне и на Западе в целом настроениям в отношении СССР. 6 октября он пишет министру Х. Каммингсу: «Здесь в России дела идут в обычной русской манере. Как это понимать? Ситуация отчаянно озадачивающая. Но в чём я совершенно уверен, так это в том, что нынешнее правительство состоит из очень способных и сильных людей, которые хорошо владеют ситуацией. Сообщения, которые превалируют в Западной Европе, на тот счёт, что режим разваливается и по существу падает, принимают желаемое за действительное и не отражают того, что могло бы быть подкреплено фактами. Конечно, ужасно и прискорбно созерцать, как эти расстрелы продолжаются, и лично я всегда буду считать, что эта в своей основе вселяющая оптимизм попытка поднять уровень жизни масс запятнана и принижена политикой, которая осуществляется таким ужасным и тираническим путём... Они делают здесь так много хорошего, что это поистине прискорбно» ${ }^{6}$.

Могут сказать: а какое все это имеет отношение к нашей теме? Самое непосредственное. Мощная пропагандистская завеса, созданная вокруг СССР усилиями «умиротворителей», серьёзно дезориентировала западную общественность в отношении подлинных угроз, исходящих от держав агрессоров, и, напротив, породила большую настороженность к политике и намерениям Москвы. В то же время Гитлера долгое время воспринимали как эдакого «обиженного ребенка», которому надо было помочь встать на ноги, т.е. избавить от несправедливостей Версальского договора, чтобы он успокоился. В конце концов, в отличие от загадочного большевистского деспота Сталина (помните: «Чингисхан с телефоном», как окрестил его Р. Роллан) он был «свой», из одной и той же семьи, хотя и не без врожденного уродства.

С особым пиететом во влиятельной части американской правящей элиты относились к Гитлеру - востребованной временем сильной личности в эпоху социальных потрясений, гению «корпоративного государства». Это уже после того, как нацистский фюрер «выйдет из-под контроля» и поднимет руку на самих «умиротворителей» он превратится в «кровавое чудовище» и врага всего человечества. А пока он был известен как человек порядка в раздираемой противоречиями послевоенной Германии и принципиальный борец с коммунизмом, умеющий гипнотизировать разуверившуюся толпу.

Американцы рано выделили его как яркую личность среди безликих деятелей Веймарской республики и не спускали с него глаз вплоть до его прихода к власти. Интересно свидетельство на этот счёт в мало известных дневниках американского военного атташе в Берлине Трумэна Смита. Он не скрывал своего восхищения личностью и организаторскими способностями Гитлера, когда впервые встретился ним ещё в 1922 г. «Великолепный демагог. Я редко слышал столь логически мыслящего и фанатичного человека. Его власть над толпой,

${ }^{6}$ Library of Congress. Manuscript Division, Joseph T. Davies. Chronological File, 1936 - 1938. Box 6, J. Davies Journal, October 6, 1937. 
должно быть, беспредельна», - записал он «по свежим следам». Хорошо зная о настроениях в США в годы «великого красного страха» и пальмеровского террора, Гитлер пустил в ход беспроигрышную карту в последовавшей беседе с американцем. Он подчеркнул, что его движение (тогда оно едва насчитывало 100 чел.) преследует цель «противостоять марксизму», и далее предостерегал: «Если Америка не поможет германскому национализму, большевизм завоюет Германию. Тогда... русский и германский большевизм чисто из самосохранения нанесут удар по западным странам» [6, с. 48, 52-54, 60-61].

Особая тема - участие американских корпораций в восстановлении военного потенциала Германии в нарушение ограничений Версальского договора. Тема, которая не получила своего развития на Нюрнбергском процессе, как уже отмечалось в одной из наших последних публикаций журнала [1]. Оказывается, большой грех на душу взяло сталинское руководство в период подготовки процесса, вступив в тайный сговор с американцами, как стало известно из недавно опубликованных дневников генерала И.А. Серова, и осуществив своеобразный «размен» наиболее щекотливых с точки зрения интересов сторон вопросов. По свидетельству одного из руководителей советской контрразведки генерала П.В. Федотова, входившего в комиссию по подготовке процесса, «американцы пошли нам навстречу, сняв вопрос о секретных протоколах Молотова - Риббентропа 1939 г. в обмен на то, что мы не поднимаем вопрос о финансовых связях США с гитлеровскими промышленниками [3, с. 536-537]. Остаётся только гадать, сколько ещё подобных тайн хранится в архивах у нас и за рубежом.

Интересно, что в наши дни известная реабилитация Гитлера на Западе началась даже не столько с публикации в ФРГ «по истечении срока давности» нацистской библии «Майн Кампф» с 700-страничными «научными» комментариями, сколько с попыток отобразить «феноменальные» личные качества Гитлера, его гениальную «харизму» [15]. Прямо надо сказать, что авторы этих работ в погоне за скандальной известностью выглядят довольно беспомощно, пытаясь показать «магнетизм» фигуры нацистского вождя на фоне его кровавых преступлений. Остается только удивляться, что эта скользкая тема не получила пока адекватной оценки со стороны некоторых международных организаций, обычно внимательно отслеживающих любые покушения на проблему Холокоста. Как будто можно всерьёз повествовать об «обаянии» маниакального приверженца «окончательного решения» еврейского вопроса в отрыве от газовых камер Освенцима. Правда, кровавый антисемитизм Гитлера почему-то не мешал заигрывать с ним администрации Рузвельта, в составе которой было немало лиц с еврейскими корнями.

А в Москве, по мере обострения ситуации в Европе и на Дальнем Востоке, внимание посла Дэвиса всё больше переключается на военные вопросы. Его единомышленником в оценке «намерений и потенциалов» сторон был американский военный атташе полковник Филипп Феймонвилль, которого недолюбливали в военном ведомстве в Вашингтоне за независимый нрав и «симпатии к русским». 
В апреле 1938 г., т.е. в самый канун общеевропейского кризиса вокруг Чехословакии, Феймонвилль по заданию посла подготовил обширный документ под характерным названием «Военная мощь Советского Союза», в котором дал оценку боеспособности Красной Армии. В частности он отмечал: «Красную Армию на апрель 1938 г. можно рассматривать как мощную военную организацию, состоящую из великолепных солдат, великолепных младших командиров и, по меньшей мере, неплохого старшего комсостава. Армия вооружена хорошим стрелковым оружием, имеет на вооружении очень приличные самолёты и превосходные танки. Её артиллерия вполне удовлетворительна и быстро совершенствуется. Армия опирается на огромную оборонную промышленность, которая в высшей степени централизована и способна подчинить все ресурсы страны осуществлению программ вооружений».

И далее: «Оборонительные позиции Советского Союза в своей основе очень прочные. Было бы по существу невозможно в буквальном смысле слова завоевать Советский Союз. Враг мог бы скорее надеяться на внутренний крах советского режима, но Советское правительство, хорошо зная о такой эвентуальности, предпринимает все возможные предосторожности с тем, чтобы вооружённые силы сохраняли лояльность правительству и чтобы в стране не появились какие-либо оппозиционные группы, которые могли бы угрожать власти Кремля. В военном отношении Советский Союз может устоять в одиночку против любой комбинации из двух враждебных держав. Если бы Советскому Союзу угрожала военная коалиция из более чем двух держав, часть его территории, возможно, была бы оккупирована, но, скорее всего, нынешние вооруженные силы Советского Союза не допустят решающего поражения и маловероятно, что вторгнувшиеся армии добьются окончательной победы» ${ }^{7}$.

Заметим, что этот документ, отражающий мнение посла и весьма прохладно встреченный в Вашингтоне, был подготовлен за три с лишним года до начала Великой Отечественной войны, когда Феймонвилль, вновь оказавшись в том же качестве в Москве, сумел сам проверить точность своих довоенных прогнозов. Эти прогнозы, разумеется, отражали конкретное соотношение сил на тот момент, когда Германия ещё не набрала дополнительную мощь, и её легко можно было остановить именно во время Судетского кризиса. Отсюда, возможно, в свете последующих событий и несколько оптимистические оценки военного атташе о способности Советского Союза выдержать одновременное нападение двух агрессоров, скорее всего, речь шла о Германии и Японии. Слава богу, что судьбе было угодно не испытывать Советский Союз на прочность в 1941 г. нападением агрессора ещё и на Дальнем Востоке, от которого СССР всё время был на волоске.

По мере того как европейский кризис вступал в решающую фазу, голос посла из Москвы всё больше диссонировал с превалирующими в Вашингтоне

\footnotetext{
7 Library of Congress. Manuscript Division, Joseph T. Davies. Chronological File, 1936 - 1938, box 7, J. Davies Journal, April
} 17,1938 
настроениями, особенно в оплоте консерваторов - Госдепартаменте. На смену Дэвису прибудет кадровый служака Лоуренс Штейнгардт, который будет пророчить Советскому Союзу после 22 июня 1941 г. скорую гибель. Что касается самого Дэвиса, то известной проверкой его востребованности на ключевых постах явился многозначительный отказ Рузвельта на просьбу направить его главой американского посольства в Берлин. О многом говорил тот факт, что на смену либералу и учёному-пацифисту Уильяму Додду туда был направлен профашистски настроенный Хью Вильсон. «Смена караула» в ключевых точках ясно говорила о том, что в Вашингтоне на местах хотели иметь людей, понимающих его «генеральную линию» с полуслова по мере приближения международной ситуации к кульминации.

Честному Дэвису пришлось принять более скромное назначение на пост американского посла тогда в провинциальном Брюсселе. Но и оттуда он будет продолжать предостерегать Вашингтон о пагубности политики «умиротворения» агрессоров и важности сотрудничества с СССР. Перед тем как отбыть к новому месту службы, он направил государственному секретарю Хэллу обстоятельную телеграмму (в то время, заметим, было не принято как у нас, так и у американцев экономить на связи и ограничивать шифротелеграммы 3-5 страницами текста), в котором содержались такие шокировавшие Госдепартамент строки: «По моему мнению, следующее поколение станет свидетелем того, как эти люди здесь (в Советском Союзе. - А.Б.) будут оказывать колоссальное влияние не только на положение дел в Европе, но и во всем мире... Великие силы таятся здесь и ещё более великие силы вызревают. Они неизбежно вызовут далеко идущие последствия». Воистину, взгляд сквозь годы, хотя и чужой. Если бы мы сами ещё умели не быть себе врагами!

В политике есть такое понятие как идеологическая зашоренность или неспособность сойти с взятого курса, какие бы факты не ставили его под сомнение. Бывает трудно отказаться от полюбившейся цели, хотя все говорит о ее несбыточности, а то и о возможных роковых последствиях. Среди солидных монографий, приуроченных к 100-летию со дня начала Первой мировой войны, была одна работа, которая, может быть, в чем-то упрощенно, называлась «Лунатики» (The Sleepwalkers) - о государственных деятелях того времени, якобы против своей воли ввергнувших мир в первую кровавую бойню [8]. Скорее всего, большие и малые войны начинались как в результате стратегических просчётов, так и опасных идеологических заблуждений, принятия желаемого за действительное. В политике особенно трудно предвидеть результат, когда авантюрное начало сталкивается с традиционным, классическим. Простая арифметика здесь не помогает.

Вчерашний ефрейтор или «богемский капрал», как презрительно называл его престарелый фельдмаршал Пауль фон Гинденбург, из рук которого Адольф Гитлер получил власть, не был традиционным политиком. Его представление о возможном и невозможном не укладывалось в рамки немецкой «реалполитик» 
и, наверное, повергло бы в ужас таких классиков старой школы, как Карл Клаузевитц или Отто фон Бисмарк. Его приход во власть объяснялся затянувшимся глубочайшим кризисом, поразившим Германию после проигранной мировой войны и навязанного ей несправедливого Версальского мира. Немецкие промышленники и финансисты ждали от него наведения социального порядка в стране и изменения правил конкуренции вовне, если потребуется с применением военной силы. Их партнёры и конкуренты, прежде всего, победители - англосаксы, видели в нацистской партии и её вожде силу, способную противостоять социально враждебному Советскому государству. Нужно было только помочь «послевеймарской» Германии встать на ноги и не допустить её преждевременного «схода с дистанции». Этой цели и служила западная политика «умиротворения», пиком которой и стал Судетский кризис. К моменту его возникновения нацисты имели уже большой опыт достижения поставленных целей, как в вопросах преодоления военных, так и территориальных ограничений Версальского договора. В рамках нашей темы нет смысла подробно останавливаться на всех «победах» Гитлера на дипломатическом фронте. Стоит лишь отметить, что этот опасный авантюрист каждый раз очень трепетал за успех очередного рискового предприятия и боялся получить по рукам от своих противников. За его внешней уверенностью скрывался животный страх. Красноречивым примером служил захват Рейнской демилитаризованной зоны в марте 1936 г.

Это был первый серьёзный вызов европейскому миру со времен прошедшей войны и вместе с тем глубокий зондаж, если не сказать «разведка боем», позиции западных держав, прежде всего Франции. О том, что творилось в тот момент в душе нацистского фюрера, ринувшегося, как считали многие его приближённые, в чреватую крахом авантюру, можно судить по воспоминаниям одного из близких к нему людей - Альберта Шпеера. «Нервничая, Гитлер ждал первой реакции. В специальном поезде, в котором мы ехали в тот день (7 марта) в Мюнхен, царила от вагона к вагону напряженная атмосфера, исходившая из купе, занятых фюрером. На одной из станций в вагон было передано сообщение. Гитлер вздохнул с облегчением: "Наконец - то! Король Англии не вмешается. Он верен своему обещанию. Это означает, что всё может сойти благополучно”. «Тем не менее, - продолжает Шпеер, - он был чрезвычайно взволнован и даже позже, когда он вёл войну почти против всего мира, он всегда называл ремилитаризацию Рейнской зоны “самым своим отчаянным предприятием"».

И далее Шпеер раскрывает, как блефовал Гитлер. «У нас не было армии, заслуживающей своего названия, в то время у нас не хватило бы боеспособности продержаться против поляков. (В то время немецкая армия насчитывала 100 000, а польская - 300000 чел. - А.Б.). Если бы французы предприняли какиелибо действия, мы были бы легко разбиты, нашего сопротивления не хватило бы и на несколько дней. А о наших военно-воздушных силах тогда нельзя было говорить всерьёз. Несколько гражданских «Юнкерсов-52», которым, к тому же, не хватало даже бомб» [16]. 
Было бы чрезмерным упрощением, чем грешила советская историография, считать, что политикой главных «умиротворителей» руководил лишь один классовый инстинкт - стремление в нужный момент подтолкнуть Гитлера на восток против Советского государства. На самом деле тесно переплетались многие факторы, Старые колониальные державы Англия и Франция боялись требования Германии о возвращении ей колоний, потерянных по итогам войны, и поэтому были не прочь удовлетворить её аппетиты в Европе. Американцам, как и немцам, вообще была близка тема «ревизии» Версальского договора, как не оправдавшего их ожиданий, как, впрочем, и всего построенного на нём межвоенного мирового порядка с сохранением невыгодного им колониального компонента.

Это в следующем веке, выиграв холодную войну, американцы будут дорожить построенным на фундаменте их гегемонии мировым порядком, обвиняя Россию в «ревизионизме», а себя вместе с зависимыми от них европейцами изображать «охранителем статус-кво». А в то смутное межвременье международная стабильность лишь на словах волновала Вашингтон. Тогда США выступали в роли ревизионистской «восходящей державы», как сегодня западные политологи нередко изображают Китай, стремились поживиться, как станет принято говорить, плодами «управляемого хаоса» в международных отношениях. Пресловутый изоляционизм был лишь оборотной стороной игры на мировых противоречиях с целью дестабилизации всей мировой системы.

Известную роль в массовой психологии «умиротворения», особенно в восприятии его логики западным общественным мнением, играла запредельная цена победы стран Антанты в Великой войне, пока она была ещё, как верили, первой и последней по такому масштабу и числу жертв. Западные политики умело играли на пацифизме, объясняя своим «миролюбием» потворствование агрессорам. Французы вколачивали огромные средства в «линию Мажино», надеясь с её помощью оградить себя от новой агрессии из-за Рейна и не понимая, что в век мобильной войны время крепостей в духе инженерной мысли выдающегося военного инженера своего времени, маршала Франции, маркиза де Вобана навсегда ушло в прошлое. Во многом такая психология «осаждённой крепости» порождала настроения обречённости, пораженчества и капитулянтства, которые привели европейцев к потере национальной независимости. Боязнь новой крови привела к её потокам доселе в невиданных масштабах.

Вот характерное свидетельство на этот счёт одного из западных авторов: «Так же как и французы, - пишет он, - англичане были сильно ошеломлены ценой сухопутных сражений мировой войны. Три четверти миллиона англичан или 9\% всего мужского населения в возрасте до 45 лет, погибли и полтора миллиона были ранены или отравлены газами. Английские лидеры всячески стремились избежать повторения такого побоища на континенте» [14, с. 144]. Причём англичане, словно это было в XIX в., а не в век авиации и, как потом оказалось, и ракет, считали, что они вновь, как в эпоху наполеоновских войн, 
отсидятся за Ла-Маншем, и поэтому активно подталкивали к «умиротворению» Германии более географически уязвимых и морально надломленных войной французов.

Как это ни покажется кому-то парадоксальным, но стратегия Гитлера, несмотря на всю его антикоммунистическую риторику, была куда меньше отягощена классовыми мотивами, чем действия западных демократий, и следовала скорее законам геополитики. Главным в этой стратегии было учесть печальный опыт недавней войны и не допустить заведомо проигрышной для Германии войны на два фронта. Прежде чем начать войну против России - главного препятствия на пути Третьего рейха к покорению Европы, - надлежало обезопасить тылы, т.е. разбить Францию и так или иначе нейтрализовать Англию. В отношении Соединённых Штатов Гитлер до последнего момента верил, что «великая еврейская плутократия» не станет вмешиваться в европейские дела и будет сохранять заявленный нейтралитет.

Именно в таком духе обсуждались вопросы военной стратегии на совещании Гитлера с высшими военными чинами рейха 5 ноября 1937 г. «Германская политика, - указывал он, - должна иметь в виду двух заклятых врагов - Англию и Францию, для которых мощный германский колосс в самом центре Европы является бельмом на глазу...». Перед немецким генералитетом была поставлена задача разгрома Чехии и одновременно Австрии, чтобы снять угрозу с флангов при возможном наступлении на запад. При этом уже тогда расчёт строился на том, что «Англия, а также предположительно и Франция втихомолку уже списали со счетов Чехию и согласились с тем, что когда-нибудь этот вопрос будет решён Германией» ${ }^{8}$. Роль Франции ставилась под сомнение в связи с подписанным ею в 1935 г. Договором о взаимопомощи с Чехословакией, который наряду с заключенным в том же году Советско-чехословацким пактом о взаимопомощи, вполне могли стать надежной гарантией суверенитета Чехословакии, разумеется, при условии их точного и своевременного выполнения.

Малоизученная сторона дела - реакция приглашённых участников совещания, воспитанных в прусских военных традициях, Бисмарка и Мольткестаршего («политика есть искусство возможного», а война, как известно, «продолжение политики иными средствами»). Эта реакция со стороны большинства собравшихся была настороженной, если не сказать скрыто-враждебной. Сказанное фюрером - нижним чином и дилетантом в вопросах военной стратегии, многим показалось верхом опасного авантюризма. Слишком мало прошло времени после позора Компьена и Версаля, ещё свежа была горечь поражения и живо поколение проигравших, а Германия была слишком слаба и неподготовлена, чтобы всерьёз думать о реванше. В результате в верхушке старого прусского офицерства, не принявшего догмы нацизма и испытывавшего откровенное призрение к личности нового вождя нации, начал зреть серьёзный заговор.

8 Документы и материалы кануна Второй мировой войны. 1937-1939. Т. 1. Ноябрь 1937 г. дек. 1938 г. М.: Политиздат, 1981. C. 27, 30-31. 
Во главе его стояло всё высшее руководство вермахта - генералы «старой школы» Бломберг, Фритч, Бек, Гальдер, бывший министр и мэр Лейпцига Герделер, статс-секретарь МИД Вайцзеккер и другие. Военный переворот был приурочен к вторжению немецких войск в Чехословакию. Его организаторам и в голову не приходило, что захват чужого государства может быть бескровным. Заговорщики связывали основные надежды на успех заговора с поддержкой извне, прежде всего из Лондона. С этой целью в английскую столицу в августе 1938 г. по поручению заговорщиков был направлен крупный прусский землевладелец, до 5 февраля того же года командир армейского корпуса в Бреслау Эдвард фон Клейст, где он был принят вторым человеком «Форин офис» Р. Ванситартом и в то время ещё оппозиционным У. Черчиллем. Большой любитель закулисных интриг, будущий британский премьер с энтузиазмом встретил немецкого эмиссара и, как мог, постарался воодушевить заговорщиков. Ему уже грезилось свержение Гитлера и его клики в результате военного переворота и восстановление монархии в Германии. Напротив, Ванситарт, полностью разделяя линию Н. Чемберлена на «умиротворение» Гитлера, хранил настороженное молчание.

Заговорщики весьма некстати своими действиями вносили элемент неопределённости и могли поломать отлаженную стратегию Великобритании. Не скрывая своего раздражения создавшейся ситуацией, премьер-министр 17 августа 1938 г. сообщал своё мнение лорду Галифаксу, который незадолго до этого сменил колеблющегося А. Идена на посту министра иностранных дел: «Фон Клейст настроен воинственно против Гитлера и крайне жаждет возбудить своих друзей в Германии предпринять попытку свергнуть его. Он напоминает мне якобинцев при французском дворе во времена короля Уильяма, и я думаю, что мы должны пренебречь многим из того, что он говорит» [11, с. 71]. Ещё бы, не хватало того, чтобы ради сомнительной затеи оппозиционеров поставить под сомнение успех дела поддержки нацистов. В итоге Клейст, говоря по-русски, «не солоно хлебавши», вернулся в Германию, чтобы сообщить своим товарищам обескураживающее мнение английского правительства. Дипломатический триумф Гитлера, достигнутый без единого выстрела, окончательно выбил почву из-под ног оппозиционеров и укрепил его положение среди высшего армейского офицерства.

Дух обречённости перед мощью Германии постепенно овладевал старой Европой. Сказывался исторический страх европейцев перед «тевтонами» - зачинщиками многих войн. «Мир любой ценой!», «Лучше Гитлер, чем революция», «Лучше Гитлер, чем Сталин» - пугала пресса обывателей. Эти упаднические настроения сумел почувствовать Дж. Дэвис, предпринявший по поручению Рузвельта летом 1937 г. поездку по 14 европейским странам. Белый дом, начиная чувствовать некоторую тревогу в связи с закулисной активностью англичан, хотел быть в курсе развития событий в Европе. Напомним читателю, что до «особых отношений» англосаксов было ещё далеко и Лондон уверенно играл 
самостоятельную роль, свысока поглядывая на неуклюжих американцев на противоположной стороне Атлантики.

В июле личная яхта Дэвиса «Морское облако», которую советские власти в качестве особого расположения к американскому послу разрешила держать в Ленинградском порту, в сопровождении кораблей Балтийской эскадры вышла в открытое море. За время своего месячного путешествия Дэвис подготовил и отправил в Вашингтон 12 больших докладов о состоянии европейских дел, в которых высказывал мысль о вероятности начала войны в 1938 или 1939 г. Данциг он называл «пороховой бочкой» и отмечал, что «ситуация здесь искусственно нестабильная и, вероятно, может в конечном счёте разразиться бедой». После посещения Вены и Будапешта Дэвис сообщал: «Австрийское государство в отчаянном положении как внутри, так и извне... Существует реальная возможность того, что Германия может поглотить Австрию без серьёзных трудностей практически в любое время, когда пожелает». В письме Элеоноре Рузвельт, супруге президента, он заключает: «Европейская ситуация полна трагизма... Сегодняшнее мышление в Европе столь близоруко и путано, что почти теряешь надежду» ${ }^{9}$.

Дело шло к новой европейской войне, а многие политические деятели отказывались в это верить и надеялись, что «всё так или иначе образуется». К их числу относился президент Чехословакии Эдуард Бенеш - один из главных героев нашего повествования. Личность, безусловно, противоречивая, но, можно сказать, в чём-то и последовательная, когда речь шла о принятии ответственных решений. Дэвис встретился с ним во время своего посещения Праги. У американцев было особое отношение к буржуазной Чехословакии - «витрине западной демократии», созданной на обломках империи Габсбургов, как считалось, при активном содействии президента США Вудро Вильсона - горячего сторонника фрагментации европейских империй и борца за «самоопределение малых народов». Казалось бы, что уж здесь, американцы должны были бросить на чашу весов весь свой вес и влияние, чтобы взять под защиту своё детище. Но Чехословакию ожидала другая участь.

Во время беседы с Дэвисом Бенеш вёл себя самоуверенно, уповал на силу Антанты, утверждал, что Румыния «не подведёт», но всё же до конца не мог скрыть своей тревоги, когда разговор коснулся вопроса о помощи со стороны Франции. Вот как завершилась эта беседа: «Когда я уже уходил, - записал Дэвис, он проводил меня до двери, но внезапно повернулся и сказал: «Вы задали мне вопрос, который я хотел бы задать Вам... Вы поинтересовались моим мнением на тот предмет, придет ли Франция к нам на помощь, если нападёт Гитлер. Вы, похоже, удивились, когда я ответил, что не имею и тени сомнения в том, что они выполнят свои договорные обязательства. Почему Вы спросили об этом?

- Г-н президент, - ответил я, - только лишь потому, что я задавал этот вопрос везде во время моей поездки по Европе.

9 Library of Congress, Joseph T. Davies. Chronological File. Box 6, J. Davies Journal, August 20, 1937. 
- И не скажете ли Вы мне, каков же был ответ?

- Охотно. Он был однозначным за одним исключением. Иное мнение высказал один американец в Париже. Тот сказал “нет”.

- Он (Бенеш) ничего не ответил. Вероятно, это потрясло его. Я бы предпочёл быть в состоянии пробудить его надежды, но он сам хотел, чтобы я сказал ему правду» ${ }^{10},-$ закончил Дэвис.

Загадочным «американцем в Париже», скорее всего, был Бернард Барух, крупный американский финансист и азартный игрок на Уолл-стрит, доверенное лицо президента Рузвельта, как впрочем, советник и ещё пяти президентов в течение своей долгой жизни. Дэвис встретился с ним в шикарном парижском отеле «Риц» во время своего турне по европейским столицам. Еврей Барух наотрез отказался принять приглашение своего старого друга Дэвиса отобедать на открывшейся в Париже Всемирной выставке, когда выяснилось, что заказать места можно было только в ресторане в немецком павильоне. «Его чувства, - записал в дневнике Дэвис, - были слишком обострены из-за преследований Гитлером его соплеменников. Нам не хватало его, но мы с уважением отнеслись к его решению».

Большое отражалось в малом в то драматическое время, если добавить ещё одну живописную деталь к нашему повествованию. Французские власти, видимо, не случайно отвели площадки под строительство советского и германского павильонов напротив друг друга, желая этим подчеркнуть непримиримость идеологической борьбы и антагонизмов двух смертельных врагов - нацизма и коммунизма. Французы заранее любезно ознакомили любимого архитектора Гитлера Шпеера, - исполнителя гигантских маниакальных проектов фюрера, призванных увековечить «тысячелетний рейх», с макетом советского павильона. У его входа предполагалось установить известную десятиметровую скульптуру В.И. Мухиной «Рабочий и колхозница». Общая высота композиции вместе с постаментом составляла более 30 м и, по замыслу создателей, должна была символизировать победное шествие людей труда по планете.

Когда Шпеер узнал об этом, в его голове немедленно созрел ответный замысел, за что он был потом удостоен в Берлине почётной золотой медали. По его проекту у входа в немецкий павильон была установлена огромная серая цементная кубическая глыба, увенчанная германским орлом со свастикой в когтистых лапах. Эта символика как бы подкрепляла близкую «умиротворителям» мысль о незыблемости прочного заслона в лице нацистской Германии на пути «натиска большевизма» и неотвратимости конфликта между двумя тоталитарными государствами.

Наступил 1938 г. - критический для будущего Европы и всего мира. Агрессия выходила на стратегический простор. Предлогом для Гитлера явилась забота о немецком населении в Австрии и Чехословакии, а определённым сигналом к действию послужило назначение на пост главы Форин офис хорошо известно-

${ }^{10}$ Library of Congress, Joseph T. Davies. Chronological File. Box 6, J. Davies Journal, September. 13, 1937. 
го им по визитам в Германию и близкого к Чемберлену лорда Галифакса вместо ушедшего А. Идена, расходившегося с премьером по тактическим вопросам. Как отметил в своём дневнике один из ответственных чиновников Госдепартамента, решение Чемберлена «переброситься мячом с Гитлером и Муссолини достигло конкретной стадии и не являлось более простой абстракцией» ${ }^{11}$.

12 февраля 1938 г. австрийский канцлер К. Шушниг, словно какой-то вассал, был вызван в альпийскую резиденцию Гитлера в Берхтесгадене и подвергнут там тактике «устрашения». Когда австриец в начале беседы по-светски заикнулся о чудесном зимнем пейзаже, открывавшемся из окна, Гитлер грубо оборвал его: «Мы собрались здесь не для того, чтобы говорить о красотах природы или о погоде». Говорить он собирался об «аншлюсе» Австрии как «о втором немецком государстве» и о её включении в состав Третьего рейха. Иначе, трубила нацистская пропаганда, австрийцам угрожал «большевизм».

В Лондоне и Париже расценили случившееся как «семейное дело» немцев и предпочли держаться в стороне. Дж. Дэвис записал в дневнике: «Теперь нацисты заявляют, что Шушниг является большевиком. Это слишком трагично, чтобы казаться смешным. В смелости им не откажешь по части большой лжи» ${ }^{12}$. В ночь на 12 марта 1938 г. немецкие войска вступили в Австрию, оставив по пути, по свидетельству генерала Йодля, из-за плохого технического состояния 70\% всего своего механизированного парка. «Несокрушимая» боевая мощь Германии на том этапе была сплошным блефом, к созданию которого приложило руку не только ведомство Геббельса, но и одураченные им люди на Западе, вроде известного авиатора, кумира американцев полковника Чарльза Линдберга, уверовавшего после посещений Германии, что вермахту в Европе «не было равных» [2, с. 47-67].

Жертвой агрессии стало первое суверенное европейское государство с населением в 7 млн чел. Сегодня в Австрии популярна точка зрения, которую мне приходилось выслушивать от австрийцев в Совете Европы, согласно которой судьбу их страны решила не столько внешняя агрессия, сколько корыстный выбор национальной элиты, отдавшей себя в руки более сильного, чтобы гарантировать свои привилегии. Как бы то ни было, но это привело к изменению всей военно-политической конфигурации. Отныне немецкий рейх с трёх сторон нависал над территорией Чехословакии. Гитлер считал, что «ковать железо надо было пока горячо». 21 апреля 1938 г. он вызвал к себе начальника генерального штаба генерала Кейтеля, чтобы обсудить с ним план «Грюн»- операцию по захвату Чехословакии. Ответная международная реакция большого беспокойства в Берлине не вызывала. И действительно, выступая в палате общин Чемберлен заявил, что случившееся нельзя было предотвратить, если не говорить о применении силы. Французы в этот момент переживали очередной правитель-

\footnotetext{
11 The Moffat Papers. Selections from the Diplomatic Journals of Jay Pierrepont Moffat, 1919 - 1943. Chicago: Harvard University Press, 1956. P. 18.

${ }^{12}$ Library of Congress, Joseph T. Davies. Chronological File. Box 6, J. Davies Journal, February, 15, 1937.
} 
ственный кризис и были всецело поглощены своими внутренними делами. Ну а Вашингтон? Ещё 2 марта полпред А.А. Трояновский сообщал из американской столицы, что «судьба Австрии не вызывает здесь большого беспокойства» ${ }^{13}$. А куратор европейского направления в Госдепартаменте Дж.П. Моффе, получив сообщение об «аншлюсе», меланхолично записал в своём дневнике, что «Гитлер сделал ещё один шаг к полному господству над Европой». Госсекретарь Хэлл дружелюбно принял германского посла Дикхофа и был вполне удовлетворён его разъяснением, что «аншлюс» означал «конец аномалии» и «являлся вкладом в упрочение европейского мира».

И лишь Москва в правительственном заявлении от 17 марта 1938 г. решительно осудила совершённое насилие в центре Европы и выразила готовность приступить к обсуждению практических мер вместе с другими государствами в целях предотвращения дальнейшей агрессии. Как и следовало ожидать, советское предложение не получило отклика и лишь усилило подозрения в отношении истинных намерений русских. Можно сказать, что международное доверие тогда было на нуле и это объективно работало в пользу Гитлера. Каждая сторона подозревала другую в коварных замыслах и это непосредственно сказывалось на формировании внешней политики. Принципиальное значение приобретал вопрос, чего добивался в то непростое время Советский Союз и какую цель ставила сталинская дипломатия в связи с кризисом вокруг Чехословакии.

Не вызывает сомнения, что политика Кремля до и после расчленения Чехословакии была в корне различной. Если в Москве не испытывали иллюзий в отношении двуличия Чемберлена, то определённые надежды сохранялись в отношении позиции Франции, всё-таки связанной с чехами пактом о взаимопомощи и установившей в 1935 г. договор о взаимопомощи с СССР. При этом, возможно, недооценивалось то, что во французской политике закончилась «эра Барту» и наступила «эра Даладье, Лаваля и Бонне» - будущих коллаборационистов. После большевистской революции 1917 г. в России классовый момент был решающим в европейской политике. Именно на этих весах взвешивались все «за» и «против», когда элиты, власть имущие определяли вектор национальных интересов. Между тем в Москве, определяя свою тактику в отношении угрозы, нависшей над Чехословакией, рассчитывали на то, что национальный интерес, понимаемый как защита отечества вопреки старым марксистским догмам, окажется решающим и создаст условия для отпора агрессору.

Вместе с тем ситуация оставалась исключительно щекотливой и требовала от Кремля большой осторожности и осмотрительности, чтобы не дать повод для обвинений во вмешательстве в чужие дела и «экспорте революции». Не случайно, в современном дискурсе с подачи в основном «младоевропейцев» упор уже давно перенесён с темы освобождения Европы от фашизма Красной Армией на тему её «оккупации». В этой связи основной причиной отказа правительства Бенеша обратиться к Москве за военной помощью называется боязнь «совети-

\footnotetext{
${ }^{13}$ Документы внешней политики СССР. Том 21. 1 января - 31 декабря 1938 г. М.: Политиздат, 1977. 617 с.
} 
зации» Чехословакии за 10 лет до 1948 г. В статье под характерным названием «А если бы в 1938 г. СССР нам помог?», увидевшей свет в конце прошлого года, её автор Ян Яндоурек (Jan Jandourek) утверждает: «Так или иначе, победа, хотя её трудно себе представить, привела бы к распространению советского влияния в нашей стране на десять лет раньше, чем это случилось на самом деле» [5]. Словом, имеем ещё одно утверждение об «обречённости» Чехословакии и повторение старого лозунга «умиротворителей» - «Лучше Гитлер, чем Сталин!».

Известные документы советской внешней политики не дают оснований считать, что в то судьбоносное время СССР видел своим приоритетом не борьбу с гитлеровской агрессией, а распространение коммунизма в соседних странах. Идея «мировой революции» была уже давно мертва, и Сталин скорее руководствовался традиционно державными и геополитическими интересами, нежели классовыми. Весьма сомнительно, чтобы в той конкретной исторической ситуации, окажись Красная Армия на территории Чехословакии, как и предполагал советско-чехословацкий договор, она стала бы менять существовавший социальный строй под предлогом борьбы с агрессором. Впрочем, это уже область гипотетических фантазий или модной сейчас альтернативной истории, а не строгого научного анализа. Ясно одно, что для спасения Чехословакии в условиях надвигающейся гитлеровской агрессии требовались, во-первых, твердое решение её правящей верхушки об отпоре агрессору и, вовторых, обращение за внешней помощью. Причём, наиболее важным было именно первое. Как известно, ни того, ни другого не последовало, и судьба страны была предрешена.

Но продолжим по порядку. В период с мая по сентябрь 1938 г. Европа жила Судетским кризисом, который развивался по нарастающей. Все всё понимали, но 16 марта нарком иностранных дел M.M. Литвинов заявил встретившимся с ним американским журналистам, что СССР в случае нападения на ЧСР «выполнит свои союзнические обязательства». Когда дотошные американцы, хорошо зная об отсутствии общей границы с Чехословакией, стали допытываться у него, как «СССР может оказать помощь», Литвинов ответил, что «уж какойнибудь коридор найдётся» ${ }^{14}$.

Внешняя уверенность наркома, политическая судьба которого находилась в руках Сталина и во многом зависела от успеха политики коллективной безопасности, не могла полностью скрыть двусмысленность положения Советского Союза. Вопрос о вводе советских войск в Чехословакию был делом далеко не техническим, как его порой представляли, речь шла о суверенитете соседних государств. «Коридором» могла служить лишь территория Польши или Румынии, правящие верхушки которых, особенно Польши, были настроены крайне антисоветски и к этому времени уже перестроились с ориентации на Малую Антанту во главе с ненадежной Францией на уверенную в себе Германию. Вполне вероятно, что твёрдость и дипломатическая последовательность, проявлен-

\footnotetext{
${ }^{14}$ Документы по истории Мюнхенского сговора. 1937 - 1939. М.: Политиздат, 1979. С. 57.
} 
ные в это время советской дипломатией, имели цель подтолкнуть колеблющуюся Прагу к сопротивлению, вселить в чехов мужество и избавить их от чувства одиночества и обречённости. Вполне вероятно, что если бы чехи дали отпор Гитлеру, то всем стало бы ясно, кто агрессор и кто его жертва, и в дело вступили бы механизмы коллективной защиты, включая Лигу Наций, заявило бы о себе и пацифистски настроенное общественное мнение и т.д. В этой ситуации СССР было бы намного легче прийти на помощь Праге, не боясь столкнуться с объединённым фронтом западных держав. Именно поэтому Гитлер блефовал, делая главную ставку на дипломатические, а не на военные усилия по захвату Чехословакии.

Интересно посмотреть, как виделась ситуация «с американского угла», когда события подошли к кульминации. 1 марта Дэвис сообщал в Госдепартамент, анализируя советские мотивы: «Что касается положения в Европе, то оно выглядит как мир, навязанный фашизмом. Литвинов говорит, что Франция будет следовать за Англией и что Чемберлен сделает всё, чтобы умилостивить Гитлера». Дэвис хорошо понимал, что для СССР - великой евроазиатской державы, дело не сводилось к одной только Европе, росла угроза его безопасности и на Дальнем Востоке. В середине марта он делится своими мыслями с супругой влиятельного сенатора Тайдингса: «Как и вся Европа, Россия остро и обоснованно живёт предчувствием войны. Они боятся нападения как с Востока, так и с Запада. Огромные поставки военных материалов и проч. направляются Красной Армией на Восток из-за боязни японского удара. Они боятся, что у них нет друзей и что они должны полагаться только на себя... Весна и лето этого года для Европы - критическое и ответственное время» ${ }^{15}$.

Судя по дипломатическому наследию Дэвиса, он стремился подняться над идеологическими или, говоря сегодняшним языком, «ценностными» разногласиями и обращался к здравому смыслу и чувству самосохранения на Западе. 26 марта 1938 г. он пишет зам. госсекретаря Самнеру Уэллесу - человеку Рузвельта в Госдепартаменте, который был на связи с фашистскими главарями («миссия Уэллеса»), что, мол, он готов согласиться с антикоммунистическими страхами англичан и французов и понимает истоки их враждебности к стране Советов. «Но с точки зрения борьбы за выживание демократии, которая идёт в мире сегодня, ввиду того факта, что Англии и Франции непосредственно угрожает полное господство фашизма в Европе, довольно трудно понять, почему имеющиеся в наличии здесь силы не следует поддержать и использовать по меньшей мере в той степени, в какой это отвечает поддержанию международной морали и справедливости в мировых делах». И хорошо зная о подозрениях своего адресата в отношении Советского Союза, он заключал на прагматической ноте: «По моему мнению, они представляют в настоящее время меньшую реальную угрозу, чем фашистские государства» ${ }^{16}$.

${ }^{15}$ Library of Congress, Joseph T. Davies. Chronological File. Box 7, J. Davies Journal, March 17, 1938.

${ }^{16}$ Library of Congress, Joseph T. Davies. Chronological File. Box 7, J. Davies Letter to Sumner Welles, March 26, 1938. 
Некоторый свет на борьбу мнений на Западе по вопросам угрозы фашизма проливают беседы Дэвиса с английским послом в Москве лордом Чилстоном. Посланец Сент-Джеймского двора в отличие от своего американского коллеги не пользовался расположением советского руководства. Когда однажды он заикнулся о желательности получения аудиенции в Кремле по делам Комитета по невмешательству в испанские дела, то в НКИД ему было сухо отвечено, что «И.В. Сталин дипломатической деятельностью не занимается».

30 марта 1938 г. Дэвис записывает в дневнике, что он имел «долгую беседу» с Чилстоном на предмет выяснения того, что произойдёт, потерпи Чемберлен неудачу в попытках стабилизировать европейскую ситуацию путём создания нового «баланса сил», как уклончиво выразился он. «Англия потерпит перворазрядное крупное поражение, если Советы будут отчуждены тем, что выглядело бы как английская враждебность, и либо останутся нейтральными, чтобы сохранить мир для своей страны, либо, возможно, будут вынуждены принять Гитлера в качестве союзника». Отметим, что возможность такой «эвентуальности» в порядке догадки была высказана американским дипломатом, вполне возможно, ещё задолго до того, как над этим задумались в Москве как о запасном варианте. Англичанин не стал с этим спорить и, хорошо зная об установке Вашингтона своим дипломатам «не высовываться», предложил коллеге вместе с ним отправиться в Лондон и хорошенько обсудить это. Дэвису оставалось лишь бессильно воскликнуть: «Если бы я мог!»

3 апреля 1938 г. новая беседа с Чилстоном «с глазу на глаз», на этот раз по инициативе англичанина. Посол, видимо имел поручение из Лондона поинтересоваться мнением американцев в отношении позиции Чемберлена по вопросу будущего Чехословакии. Стала бы неизбежной рано или поздно война между Германией и Англией, если бы англичане продолжали придерживаться занятой позиции? (проще говоря, спасла бы Англию политика «умиротворение» от войны с Германией. - А.Б.) Дэвис ответил утвердительно, пояснив, что Гитлера так просто не остановишь. В свою очередь Дэвис поинтересовался, способны ли Англия и Франция вместе нанести поражение Гитлеру без русской помощи. Чилстон счёл такой ход (или такое развитие) событий маловероятным и заявил, что это, в конечном счёте, означало бы их поражение от объединенной мощи «оси» Берлин - Рим - Токио.

И здесь Дэвис, все-таки скорее бизнесмен, чем карьерный дипломат, что называется, дал волю своим чувствам. «Я спросил, - записал он, - какой же «чёртик» влиял на Чемберлена, препятствуя установлению противостоящей “оси” Англия - Франция плюс Россия. Я могу понять их враждебность к коммунизму. Мы все так настроены. Но нам угрожает господство над миром фашистских держав. Россия, в конце концов, та держава, которая может предотвратить прорыв Гитлера на Украину и помочь английскому флоту задушить Гитлера голодом. В ином случае Гитлер получит житницу мирового значения здесь на Украине и прямой выход к Ближнему Востоку и Азии». Ну а что же Чилстон? Тот вновь 
повторил свою уловку, предложив отправиться вдвоём в Лондон, подозревая, видимо, «коварных американцев», как и Чемберлен, в желании «столкнуть Альбион с Третьим рейхом к своей выгоде» ${ }^{17}$.

На следующий день 4 апреля 1938 г. «по горячим следам» Дэвис подытожил свои мысли в письме к старому другу, секретарю Рузвельта Марвину Макинтайру с просьбой показать письмо президенту. Послание любопытно своей логикой и глубиной анализа. Судя по его выводам, Дэвис на том этапе уже исключал возможность сохранения мира. «Фашистские державы, - писал он, - пытаются изолировать Советы от западных держав, используя жупел коммунизма, фашист Гитлер - как закопчённый котелок, который называет чайник черным. Ясно, что мировой комбинации - “оси” Берлин - Рим - Токио может противостоять только “ось” Лондон - Париж - Москва (себя американцы при любом раскладе не видели в числе активных участников мировых событий. - А.Б.) Для Англии наступит «печальный день», если она окажется зависимой от милости Германии и Италии в отношении доступа к Индии через Средиземное море. Отчуждение России от Англии и Франции может быть столь же серьёзным для демократических государств Европы, как и для Советского Союза. Русские здесь уверены в себе. Они верят, что сумеют защитить себя. Они становятся все более антигитлеровски настроенными и открыто враждебными даже ценой риска для дипломатических отношений... В Европе много желаемого принимается за действительное в отношение политической неустойчивости этого режима и его индустриального развала. Все это пустое... Этот режим надолго у власти. Страна столь богата, что, несмотря на потери и неэффективность бюрократической системы управления, она все равно накапливает богатство и будет, я думаю, продолжать делать так, пока эта группа находится в Кремле» ${ }^{18}$.

Ходом своего анализа Дэвис явно опережал время и до конца, видимо, не понимал все нюансы «большой стратегии» своего «босса», как нередко в письмах он называл Рузвельта. А президент находился под сильным влиянием политики «умиротворения» Германии и исходил из желательности и неизбежности в последующем советско-германского и советско-японского столкновения для американских интересов. По-английски это называется «убить двух птиц одним камнем», а по-русски «двух зайцев одним выстрелом». Разница, как видим, чисто стилистическая, а смысл один и тот же. Предостережения посла были верными, но не ко времени. Запад должен был пройти свою часть кровавого пути, сменить правящую элиту на национально ориентированную (У. Черчилль, Де Голль), прежде чем здравый смысл восторжествовал в политике и привёл к антигитлеровской коалиции с СССР. А пока послу оставалось лишь беспомощно разводить руками и уповать на божий промысел.

Вероятно, поэтому своё послание в Белый дом он и завершил на пессимистической ноте: «Судя по тому, как развиваются события в этом сумасшедшем

\footnotetext{
${ }^{17}$ Library of Congress, Joseph T. Davies. Chronological File. Box 7, J. Davies Journal, March 30, April 3, 1938.

${ }^{18}$ Library of Congress, Joseph T. Davies. Chronological File. Box 7, J. Davies Letter to Marvin Mclntyre, April 4, 1938.
} 
мире, я боюсь, что в какой-то момент демократии, возможно, будут чертовски рады воспользоваться мощью, которое сможет предоставить это правительство (советское. - A.Б.) в случае, если вооружённые фашисты «свихнутся». И, поверь мне, из того, что я видел здесь, если эти фашистские диктаторы будут попрежнему сходить с ума, жизнь не будет стоить того, чтобы жить, когда придется жить на условиях, которые они продиктуют» ${ }^{19}$.

Для захвата Чехословакии Берлин принял на вооружение тактику «пятой колонны», сводившейся к искусственному нагнетанию вопроса о судьбе «судетских немцев». Ничем не примечательный на вид, но отличавшейся салонной обходительностью бывший преподаватель гимнастики Карл Генлейн, вставший во главе судето-немецкой партии, получал прямые указания из Берлина, подкреплённые денежными субсидиями (15 тыс. марок в месяц). Главная его задача заключалась в том, чтобы постоянно выдвигать непомерные требования и тем самым делать их неприемлемыми для правительства Бенеша. «Мы всегда должны требовать так много, чтобы нас никогда нельзя было удовлетворить», говорил своим сторонникам Генлейн.

Проще говоря, нацистам нужен был предлог для вторжения в Чехословакию. Созданный ими «национальный вопрос», тем не менее, был воспринят в Лондоне и Париже как «веское основание» для вмешательства в дела Чехословакии и удовлетворение требований Гитлера. 20 мая 1938 г. план «Грюн» был скорректирован в сторону более тесной координации военных усилий с дипломатическим и политическим давлением начехов в расчёте на благоприятную реакцию их союзников англичан и французов. Гитлер всё ещё колебался между «мирным» и военным решением вопроса. Серьёзные сомнения у него вызывала лишь позиция Советского Союза, воодушевлявшая брошенных всеми чехов. Эту неустойчивую международную ситуацию, когда ещё можно было спасти положение, отразил «майский кризис» вокруг Чехословакии, поломавший планы Гитлера.

Вопрос об оказании действенной помощи Чехословакии рассматривался в советских руководящих кругах в качестве важнейшей военно-политической задачи. Было принято решение на самом высоком политическом уровне, о котором был немедленнопоставлен в известностьчехословацкийпосланник3.Фирлингер. 23 апреля он сообщал в Прагу: «В Кремле состоялось совещание, на котором присутствовали Сталин, Молотов, Ворошилов, Литвинов и Каганович. После доклада Александровского (советский полпред в Праге. - А.Б.) о политическом положении в Чехословакии было решено: СССР, если его об этом попросят, готов с Францией и Чехословакией предпринять все меры по обеспечению безопасности Чехословакии. Для этого он располагает всеми необходимыми средствами. Состояние армии и авиации позволяет это сделать» ${ }^{20}$.

Итак, принципиальное значение имела оговорка «если его об этом попросят», вместившая в себя все непростые особенности внутренней и междуна-

\footnotetext{
${ }^{19}$ Library of Congress, Joseph T. Davies. Chronological File. Box 7, J. Davies Letter to Marvin Mclntyre, April 4, 1938.

${ }^{20}$ Документы по истории Мюнхенского сговора. 1937 - 1939. М.: Политиздат, 1979. С. 87.
} 
родной обстановки, сложившейся к этому времен вокруг Чехословакии. Без соблюдения указанного условия не мог вступить в действие «механизм союза» и действия СССР могли быть расценены как акт агрессии и вмешательства в чужие дела. Причём с самого начала кризиса помощь Франции имела второстепенное значение и не рассматривалась как обязательное условие оказания помощи. Об этом недвусмысленно заявил через несколько дней после принятия судьбоносного для чехов решения член Политбюро, председатель Президиума Верховного совета СССР М.И. Калинин. Напомнив о том, что Советский Союз обязан оказать помощь Чехословакии в том случае, если ей помогает Франция и наоборот, он отметил: «Разумеется, пакт не запрещает каждой из сторон прийти на помощь, не дожидаясь Франции» ${ }^{21}$.

Это был совершенно ясный призыв к национальной элите Чехословакии проявить волю к сопротивлению, который в тот момент был услышан Прагой. Тем более что он был подкреплён во многом демонстративными действиями со стороны Москвы. В те дни укреплялись и переводились на особое положение западные приграничные округа, войска получали дополнительные партии оружия, прежде всего самолёты и танки, поддерживались тесные контакты с представителями чехословацкой военной промышленности и представителями вооружённых сил. В Москве немедленно откликались на все просьбы Праги о поставках оружия, главным образом самолётов. Шла напряженная «война нервов», в которой чехи в дни майского кризиса одержали полную победу.

Им было, что противопоставить агрессору. Армия была готова сражаться, её отличал высокий боевой дух, она была одной из самых подготовленных и хорошо вооружённых в Европе. На армию работали крупнейшие в Европе заводы «Шкода». Население охватил небывалый патриотический подъём. Английский военный атташе в Москве полковник Файрбрейс 30 мая 1938 г. сообщал в Лондон, что даже без поддержки извне чехословацкая армия могла бы продержаться в течение трёх месяцев. По мнению многих военных специалистов, отмечает американский историк У. Меррей, «вермахт во всех отношениях не был готов к большой войне в 1938 г.» [12, с. 222].

В ответ на угрозы из Берлина в Праге 20 мая 1938 г. была объявлена частичная мобилизация, войска выдвигались к границе, чехи демонстрировали решимость воевать. Берлин был явно не готов к такому развитию событий и был вынужден временно отступить. Удалившийся в своё альпийское убежище диктатор чувствовал себя глубоко уязвлённым и униженным «несговорчивыми чехами». Нескрываемое раздражение «неуступчивостью» Праги, отказавшейся совершить национальное самоубийство во имя «сохранения мира в Европе», испытывали в западных столицах, особенно в Лондоне. Под угрозой оказалась личная репутация самого премьер-министра. В правительственной резиденции замка в Градчанах в Праге теперь могли судить, кто яв-

\footnotetext{
${ }^{21}$ Документы по истории Мюнхенского сговора. 1937 - 1939. М.: Политиздат, 1979. С. 88-89.
} 
лялся союзником Чехословакии, а кто подталкивал её на путь национальной катастрофы.

Вот как оценивал ситуацию со слов министра иностранных дел ЧСР Крофта в своей телеграмме в Москву полпред С. Александровский после того, как кризис пошёл на спад: «Крофта несколько раз и в довольно теплых выражениях высказывал прямую благодарность за ту спокойную и твёрдую поддержку, которую он чувствовал за последнее критическое время со стороны СССР. Уверенность в том, что СССР совершенно серьёзно и без всяких колебаний намеревается и готовится оказать помощь Чехословакии в случае действительной нужды, действует очень ободряюще и успокоительно на Чехословакию». Вместе с тем в ходе беседы советский полпред почувствовал нотки самоуспокоенности с чехословацкой стороны, расчёты на помощь англичан и французов, надежды на «умеренность» требований агрессора. В ответ на это с советской стороны было сказано: «Гитлер обжёгся на своём намерении взять Чехословакию лобовым ударом... Если Чехословакия будет слабой или нерешительной, то Гитлер её съест под любым предлогом, а то и без предлога. Если она будет сильной и решительной, то никакой предлог Гитлеру не поможет» ${ }^{22}$.

Волею истории Чехословакия оказалась в центре борьбы вокруг вопроса быть или не быть новой европейской и мировой войне и оставаться ей или нет в числе независимых государств. В конечном счёте, всё зависело от того, какой путь выберет национальная элита этой небольшой по размерам, но стратегически исключительно важной восточноевропейской страны. Еще Бисмарк говорил: «Кто владеет Богемией, тот держит ключ ко всей Центральной Европе». Выбор национальной элиты к лету 1938 г. сузился: или возглавить национальное сопротивление, призвать население к оружию, рискуя разбудить неконтролируемые силы, или отдать страну под «внешнее управление», говоря языком XXI в., одной из первых в Европе встать на путь коллаборационизма и смириться с потерей национальной независимости и иностранной оккупацией. Надо сказать, что это был тяжелейший выбор, который с той или иной степенью остроты и ущемления национальных интересов будет впоследствии вставать перед многими странами, не исключая и Россию после распада СССР. Лишь ответ на него был у всех разный.

Особый трагизм ситуации с точки зрения интересов чешской и словацкой национальной элиты заключался в том, что они не отдавали себе отчёт, что столкнулись с натиском совершенно нового типа европейского государства, каким стала Германия под властью нацистов, государством криминального типа, которое отбросило законы «честной конкуренции» и занималось откровенным разбоем и грабежом частной собственности покорённых стран, подчиняя их экономики задачам военной машины вермахта и обогащению германских концернов, не говоря уже о прямой конфискации еврейского капитала по примеру самой Германии. В результате этого многих представителей национальной 22 Документы внешней политики СССР. Том 21. 1 января - 31 декабря 1938 г. М.: Политиздат, 1977. С. 299. 
элиты в Праге и Братиславе, уверенных, что деньги можно делать «при любой власти», ждало сильное разочарование, а некоторых, не успевших удрать в Лондон, застенки гестапо и даже расстрел как премьер-министра уже Богемии и Моравии Алоиса Элиаша.

Майский кризис 1938 г. вызвал замешательство не только в лагере агрессора, но и в стане «умиротворителей». Учитывая, что атака «сходу» на непокорную республику не удалась, и что она оказалась куда более крепким орешком, чем сдавшаяся без боя Австрия, было решено предпринять глубокий обходный манёвр с целью добиться полной международной изоляции Чехословакии. Лето 1938 г. прошло в интенсивном дипломатическом маневрировании европейских столиц. Тон задавал Лондон. Похоже, что для Чемберлена готовящийся сговор становился делом, чуть ли, не всей его жизни, венцом его политической карьеры. Было известно, что Гитлер установил срок вторжения в Чехословакию не позднее 1 октября, и это вносило особую нервозность в политическую обстановку.

Задача, как её видели «умиротворители» с учётом недавних неудачных уроков, заключалась в том, чтобы «полюбовно», не прибегая к военной силе выдать Гитлеру Судетскую область и при этом сделать всё возможное, чтобы изолировать Прагу от своего единственного надежного союзника - СССР. Советская помощь могла вновь спутать все карты и, как боялись в Лондоне и Париже, вызвать европейскую войну в момент, когда её больше всего хотели избежать, чтобы уберечь от поражения нацистский режим, а европейский мир - от новых социальных потрясений. Чтобы убедить чехов в «безрассудстве» дальнейшего сопротивления, Чемберлен в конце июля направил в Прагу «с посреднической миссией» престарелого лорда Ренсимена. Американский журналист Уильям Ширер, находившийся в то время в Берлине, записал в своём дневнике, что «вся миссия Ренсимена дурно попахивает... Из записей, сделанных в моём дневнике в первый и последующие дни визита Ренсимена в Чехословакию, явствует, что чехам миссия Ренсимена была предельно ясна - Чемберлен послал его, чтобы подготовить передачу Судетской области Германии» [4, с. 413].

Трагическая развязка неудержимо приближалась, несмотря на все усилия советской дипломатии переломить ход событий. Требования Гитлера, чувствовавшего себя хозяином положения, становились день ото дня всё воинственнее и непримиримее. Под давлением Запада ужесточилась политика Польши и Румынии в отношении транзита советских войск к границам Чехословакии. Если поляки с самого начала были категорично настроены против появления Красной Армии на своей территории, ссылаясь на «марш конницы Будённого» и «чудо на Висле», то румыны одно время колебались и даже обсуждали пролет над своей территорией советских бомбардировщиков, правда, на высоте не ниже 3000 м. Более того, участники «санитарного кордона» поляки и хортистская Венгрия, поощряемые из Берлина, имели собственные планы в отношении части территории Чехословакии (Тешинская Силезия, часть территории Словакии). 
А как в тот момент виделась ситуация на другой стороне Атлантики в Вашингтоне? Вот что записал в своём дневнике шеф европейского отдела Госдепартамента Дж.П. Моффе: «Пятница, 12 августа 1938 г.... Утром зашёл чешский посланник, чтобы выразить возросшее беспокойство по поводу ситуации в Европы. Кажется, всё, что происходит, делает перспективы ещё хуже. Последние сообщения из Германии о мобилизации автомобильного транспорта, почтовых автобусов и тому подобного в районе Баварии, переброска германских войск всё указывало на возрастание напряжённости. Он чувствовал, что по многим признакам ситуация была хуже, чем во время кризиса 21 мая... Он дал понять, что если госсекретарь был намерен выступить с новым заявлением по типу того, которое было сделано 28 мая, то он надеялся, что это будет сделано достаточно быстро. Я осторожно ответил, что госсекретарь внимательно следит за развитием событий и пытается выявить их значение».

Ничего не скажешь, просто верх дипломатической эквилибристики. А дальше уж совсем цинично. «Президент (Рузвельт) вернулся и провёл в это же утро заседание кабинета. Одним из его первых результатов была просьба к А. Берли (замгоссекретаря) подготовить две речи для президента ко вторнику, с которыми он собирался выступить в Канаде. Берли пригласил меня обсудить одну из них, которую он хотел посвятить европейским делам. С первого же захода мы не придумали ничего лучшего, как поумничать на тему о вечной неопределённости американской внешней политики, а именно о том, что нашим лучшим вкладом будет породить сомнения в умах Германии и Ко в отношении того, что при всех обстоятельствах мы останемся в стороне, и в то же время заронить сомнения в умах Англии и Ко на тот счёт, что они смогут положиться на нас в оказании прямой помощи независимо от того, что произойдёт» ${ }^{23}$. Иначе как подогреванием страстей это и не назовешь.

Между тем маятник «европейского замирения» словно застыл где-то посередине, и малейшее движение могло склонить его в ту или другую сторону. В обстановке пугающей неопределённости, когда на карту был поставлен его личный престиж, Чемберлен решает идти ва-банк и принимает решение, ошеломившее Европу, отправиться в Германию на встречу с Гитлером. «Бог мой!»только и вырвалось у нацистского диктатора, когда он прочёл послание человека, правившего огромной Британской империей и в свои 69 лет решившегося впервые в жизни на риск семичасового воздушного перелёта в самый конец Германии, в Берхтесгаден. Гитлер даже не счёл нужным перенести её куда-нибудь поближе, на берега Рейна, что сократило бы полёт вдвое.

15 сентября 1938 г. в середине дня «миротворец» прибыл в Мюнхен и оттуда специальным поездом был доставлен в альпийскую резиденцию «фюрера и канцлера». Случайно или нет, но Гитлер принимал англичанина в том же кабинете на втором этаже, где за семь месяцев до этого он обрушился на австрийца

\footnotetext{
${ }^{23}$ The Moffat Papers. Selections from the Diplomatic Journals of Jay Pierrepont Moffat, 1919 - 1943. Chicago: Harvard
} University Press, 1956. 218 P. 
Шушнига. Наци №1 выглядел мрачным и негостеприимным и особенно не церемонился с гостем. Оставив без внимания призывы Чемберлена найти почву для англо-германского сближения, пока не будет решена «судетская проблема», он метал громы и молнии в адрес правительства Бенеша, обвиняя его в притеснении судетских немцев, и угрожал войной. Премьер-министр сразу же проявил сговорчивость и подчеркнул, что «Великобритания не заинтересована в судетонемецком вопросе» и пообещал сделать всё для изоляции Чехословакии, прежде всего от России.

Лихорадочная дипломатическая активность человека с неизменным зонтиком объяснялось тем, что из Праги и Москвы поступали пугающие Запад сигналы о готовности СССР выполнить свои союзнические обязательства перед Чехословакией. Нажим на чехов со стороны англичан и французов особенно усилился после свидания Чемберлена с Гитлером. Поэтому 19 сентября Бенеш официально запросил Москву, выполнит ли СССР свои обязательства по советско-чехословацкому договору, при этом подчеркнув, что речь о помощи может идти только при условии оказания помощи французами. Вполне вероятно, что присутствие французских войск (хотя трудно сказать, как это мыслилось сделать практически), должно было застраховать деятелей в Праге от возможных классовых неожиданностей.

Тем не менее, на запрос Праги из Москвы на следующий день 20 сентября 1938 г. по дипломатическим каналам пришёл утвердительный ответ, не оставлявший никаких сомнений в отношении позиции СССР. Кроме того, согласно директиве наркома обороны СССР от 21 сентября, в Киевском особом военном округе были организованы крупные военные учения. 23 сентября нарком обороны и Генштаб дали дополнительную директиву о приведении в боевую готовность части Белорусского особого и вновь созданного Калининского военных округов и о выдвижении к госгранице ряда их оперативных объединений. Всего в боевую готовность в ряде военных округов были приведены 30 стрелковых и 10 кавалерийских дивизий, танковый корпус, семь танковых и мотострелковых бригад и другие воинские части ${ }^{24}$. Было ясно, что Москва не шутила и была готова дать отпор агрессору. Дело было за руководителями Чехословакии.

И в этот ответственный исторический момент, чувствуя, что почва уходит из-под ног, посланники Франции и Великобритании в Праге в беседе с президентом Бенешем 21 сентября 1938 г. предприняли совместный дипломатический демарш, заявив от имени своих правительств, что ЧСР, отвергая англофранцузские предложения, берёт на себя риск войны, и просили подумать о «способе, как принять англо-французские предложения, что является единственной возможностью предотвратить непосредственную агрессию Германии». В противном случае они грозили, что «снимают с себя ответственность за всё, что произойдет». «Это ультиматум», - сказал президент Бенеш. На что английский и французский посланники ответили: «Нет, это только советы».

\footnotetext{
${ }^{24}$ Документы по истории Мюнхенского сговора. 1937 - 1939. М.: Политиздат, 1979. С. 240, 254-256.
} 
И «они требуют немедленного ответа, иначе Чемберлен не сможет поехать к Гитлеру, и Гитлер, очевидно, выступит. (Вероятно, Гитлер предъявил им нечто вроде ультиматума)», - подчеркнул министр иностранных дел ЧСР К. Крофта, ведший запись этой беседы $)^{25}$.

Вечером в тот памятный сентябрьский день, который войдёт в историю как день предательства и позора, после лихорадочных правительственных консультаций англо-французский ультиматум был «с горечью» принят Прагой. Участники того исторического заседания сами успокаивали себя, что лучше мол отдать часть, чем потерять всё. Выступая в тот же день 21 сентября 1938 г. в Лиге Наций М.М. Литвинов от имени Советского правительства отмежевался от принятых решений и заявил, что капитуляция Чехословакии «рано или поздно будет иметь совершенно необозримые катастрофические последствия» ${ }^{26}$.

С согласием Бенеша в кармане воодушевленный Чемберлен утром 22 сентября отправился на новую встречу с Гитлером, на этот раз в небольшой рейнский городок Годесберг, где остановился в старинном отеле «Петерсхоф». Гитлер ожидал премьера на противоположном берегу Рейна в отеле, владелец которого некий герр Дизен был старинным приятелем фюрера. Здесь и предстояло закрепить грязную сделку. Однако неожиданно Гитлер, почувствовав себя хозяином положения, взвинтил свои требования. Это касалось размеров требуемой территории и сроков её передачи, а также удовлетворения польских и венгерских территориальных притязаний.

Теперь настал черед Чемберлена воскликнуть: «Но это, ни больше, ни меньше, как ультиматум. Или требованиям канцлера лучше подходит немецкое слово диктат?» - язвительно произнес он. На что Гитлер явно издевательски парировал: «Это совсем не диктат. Посмотрите, документ именуется «меморандум». В историю этот документ вошёл как Годесбергский меморандум - свидетельство ненасытных аппетитов агрессора. Удручённый случившимся, Чемберлен не решился принять документ и счёл более благоразумным забрать его с собой в Лондон. В конце концов, тактика «выкручивания рук» чехам имела свои пределы. В переговорах неожиданно возникла зловещая пауза, которая грозила сорвать почти уже готовую сделку.

И тогда среди замешательства «умиротворителей» родилась идея четырехсторонней конференции европейских держав в духе давно вынашиваемой ими идеи «пакта четырёх». На этот раз инициатива исходила из Вашингтона, обеспокоенного возникшей паузой в решении «чешского вопроса». Предпочитавший до этого держаться в тени, Рузвельт рискнул выйти на авансцену европейской политики. В Белом доме и Госдепартаменте закипела работа по подготовке его обращения к европейцам с призывом «мирно» уладить свои споры. Как следует из дневника министра финансов США Г. Моргентау, это подразумевало полное

\footnotetext{
${ }^{25}$ Документы по истории Мюнхенского сговора. 1937 - 1939. М.: Политиздат, 1979. С. 245-246.

${ }^{26}$ Документы по истории Мюнхенского сговора. 1937 - 1939. М.: Политиздат, 1979. С. 262.
} 
удовлетворение требований Гитлера [7, с. 501]. 26 сентября 1938 г., исключив из окончательного текста какое-либо упоминание о возможном посредничестве США, Рузвельт обратился к Праге, Берлину, Лондону и Парижу с настойчивым призывом продолжать переговоры, что в тех условиях могло означать только одно - скрытую поддержку требований Гитлера. Причём Москва не была включена в число адресатов «пастырского» послания. Это окончательно деморализовало деятелей в Праге.

На следующий день, видя, что ситуация остается без изменений, Рузвельт направил миротворческое послание Муссолини, которого втайне считал более порядочным деятелем, чем Гитлера, и в тоже время повторил свой призыв лично к германскому канцлеру продолжать «неутомимые поиски мира». Память присутствовавших в Овальном кабинете сотрудников закрепила, как, не выпуская изо рта привычного мундштука с дымящейся сигаретой, возбуждённо советуясь с приближёнными и поблескивая стеклышками пенсне, Рузвельт на этот раз собственноручно набросал текст телеграммы Гитлеру с призывом созвать международную конференцию для мирного урегулирования конфликта. Местом встречи американцы хотели бы видеть нейтральную Гаагу, но окончательный выбор пал на баварский Мюнхен, как того захотел Гитлер ${ }^{27}$.

А дальше последовали те хорошо известные события, к которым мало что можно добавить. Утром 29 сентября Гитлер отправился в местечко Куфстейн на бывшей австро-германской границе для трогательной встречи Муссолини. На обратном пути в Мюнхен, раскрывая свои ближайшие планы, Гитлер говорил дуче: «Приближается время, когда нам придется воевать бок о бок против Франции и Англии» [10, с. 119]. Холодно встреченные двумя диктаторами в «коричневом доме» на Кёнигплатц, где после полудня начались переговоры, Чемберлен и Даладье и не подозревали, что из охотников они уже становились дичью. Переговоров в общепринятом смысле этого слова, собственно говоря, и не было. Предстояло лишь утвердить отдельные детали ранее выработанной сделки о расчленении Чехословакии и установить конкретные сроки ввода немецких войск в Судетскую область, начиная с 1 октября. Хотя на соглашении стояла дата «29 сентября», в действительности его подписание состоялось уже после полуночи.

А дальше оставалось лишь сообщить о состоявшейся сделке двум чехам посланнику в Берлине д-ру В. Мастны и чиновнику министерств иностранных дел X. Масарику, терпеливо, как и полагается побеждённым, дожидавшимся приговора в соседней комнате. Гитлер высокомерно отказался принять участие в этой простой формальности, и вынесением вердикта «без права обжалования» пришлось заниматься Чемберлену и Даладье. Время было уже позднее, и премьер-министр, утомлённый заботами дня, непрерывно зевал, не проявляя никаких признаков смущения. «Нам было объяснено довольно грубым обра-

\footnotetext{
${ }^{27}$ Moffat Papers. Selections from the Diplomatic Journals of Jay Pierrepont Moffat, 1919 - 1943. Chicago: Harvard
} University Press, 1956. 309 p. 
зом, - сообщали в Прагу чешские представители, - и притом французом, что это приговор без права апелляции и без возможности внести в него исправления... Мы простились и ушли. Чехословацкая Республика в границах 1918 г. перестала существовать» ${ }^{28}$.

Оставим за скобками ликование толпы в Лондоне, собравшейся у входа в резиденцию премьер-министра на Даунинг-стрит, 10, чтобы поприветствовать «старого доброго Невиля», заполучившего подпись Гитлера на англо-германской декларации с клятвенными обязательствами «вечного мира», не просуществовавшими и года, как, впрочем, и точно такие же обязательства, взятые перед французами двумя месяцами позже. Особое удовлетворение испытывали за океаном. Президент выступил в роли миротворца и при этом не скомпрометировал себя прямым участием в сомнительном предприятии. Для места в истории это, ох, как важно. Воздав для порядка должное британскому премьеру за его подвижнические усилия лаконичным телеграфным текстом: «Молодец!» (Good man!), Рузвельт верил, что Америка была на правильном пути. В середине октября он писал американскому послу в Риме У. Филипсу: «Я хочу, чтобы Вы знали, что я ничуть не расстроен конечным результатом» [9, с. 109].

Мюнхенская трагедия свершилась. Меньше чем через полгода Гитлер разорвал подписанное соглашение и оккупировал всю Чехословакию. Только тогда её элита полностью осознала, что совершила акт национального самоубийства, но было уже поздно. В Европе начинался предвоенный политический кризис. Москве было о чём задуматься в создавшейся качественно новой международной ситуации. Сталин болезненно переживал неудачу в Чехословакии и считал, что его крепко надули. Недоверие к западным партнёрам с тех пор стало фирменной чертой его стиля. Первой его жертвой стал горячий сторонник коллективной безопасности нарком Литвинов, отправленный в отставку в мае 1939 г. Страна оказалась в полной международной изоляции. Необходимо было любой ценой разомкнуть сжимающееся кольцо враждебных государств. Неотвратимо вставал вопрос о принципиальной смене внешнеполитического курса. То, что ещё недавно казалось абсолютно невероятным и неприемлемым по идеологическим соображениям, с точки зрения прагматической логики становилось неизбежным. Остановить агрессию коллективными средствами не удалось. Пришла пора позаботиться о собственных национальных интересах.

\section{Список литературы}

1. Борисов А.Ю. Нюрнберг-2, или несостоявшийся суд над спонсорами нацизма // Новая и новейшая история. 2016. № 3. С. 20-30.

2. Гудериан Г. Воспоминания немецкого генерала. М.: Центрполиграф, 2013. 576 с.

3. Серов И. Записки из чемодана. М.: Просвещение, 2016. 688 с.

4. Ширер У. Взлёт и падение Третьего рейха. Т. 1. М.: Политиздат, 1991.653 с.

5. Яндоурек Я. А если бы в 1938 году СССР

\footnotetext{
${ }^{28}$ Документы и материалы кануна Второй мировой войны. 1937-1939. Т. 1. Ноябрь 1937 г. — дек. 1938 г. М.: Политиз-
} дат, 1981.236 с. 
нам помог? [Электронный ресурс] // URL: http:inosmi.ru/politic/20161004/237963267.html (дата обращения: 19.11.2016)

6. Berlin Alert. The Memoirs and Reports of Truman Smith, Hassen - Stanford, 1984.

7. Blum J. From the Morgenthau Diaries. The Years of Crisis, 1928 - 1938. Boston: Houghton Mifflin Company, 1959. 583 p.

8. Clark C. The Slleepwalkers. How Europe Went to War in 1914. London: Penguin, 2012. 607 p.

9. Hearden P. Roosevelt Confronts Hitler. America's Entry into World War II. Decalb: Northern Illinois University Press, 1987. 340 p.

10. Hibbert C. Benito Mussolini. The Rise and Fall of il Duce. London: Penguin Books, 1962. 340 p.

11. Lamb R. The Ghosts of Peace. 1935 - 1945. Wilton, 1987. 353 p.
12. Murray W. The Change in the European Balance of Power, 1938 - 1939. The Path to Ruin. Princeton: Princeton University Press, 1984. 494 p.

13. Pillar P.R. The Age of Nationalism // The National Interest. September - October, 2013. [Электронный ресурс]. URL: http://nationalinterest.org/ article/the-age-nationalism-8954 (дата обращения: 19.11.2016)

14. Posen B. The Sources of Military Doctrine. France, Britain and Germany Between the World Wars. Ithaca: Cornel University Press, 1984. 283 p.

15. Rees L. The Dark Charisma of Adolf Hitler. Leading Millions into the Abyss. London: Ebury Press, 2013. 480 p.

16. Speer A. Inside the Third Reich. New York: Avon, 1970.596 p.

\title{
Oб авторе:
}

Александр Юрьевич Борисов - д.и.н., профессор Московского государственного института международных отношений МИД России, Чрезвычайного и Полномочного посланника II класса.

E-mail: albor@rambler.ru.

\section{MUNICH CRISIS: BEHIND - THE SCENE HISTORY}

\author{
A.Y. Borisov \\ DOI 10.24833/2071-8160-2017-3-54-91-122 \\ Institute of World History, Russian Academy of Science
}

The article links the tragic historical past of Czechoslovakia, which paid its price for the rejection of sovereignty as a result of its elite's national policy, with the current political discourse around globalization and national interests, the influence of external forces on the policies of dependent states, and often the negative consequences of this influence.

Much of today's policies of the leading Western powers, primarily the United States, echo their actions during the preparation and implementation of the Munich conspiracy. Playing on international contradictions while staying aside, turning in a victim to an aggressor, etc. are dangerous policies both in the past and today and lead to serious international consequences for their organizers and inspirers.

Unlike numerous works on this subject, which have appeared in Russia and abroad, focusing mainly on the activities of European «appeasers», the author of the article shows the hidden role of American diplomacy in deciding the fate of Czechoslovakia. The US was headed by President Franklin Roosevelt - an acknowledged master of the game on international controversies, avoiding being on the foreground of world politics on dubious issues.

To clarify the role of the US in European politics during the Munich crisis, the article draws on original sources from the archive of the American ambassador to the Soviet Union, J. Davis from the Library of Congress. 
Key words: USA, Roosevelt, national interest, Munich collusion, diplomacy, World War II.

\section{References}

1. Borisov A.Ju. Njurnberg-2, ili nesostojavshijsja sud nad sponsorami nacizma [Murnberg-2 or unfinished justice towards the Nazi sponsors]. Novaja $i$ novejshaja istorija. 2016. No 3. pp. 20-30. (In Russian).

2. Guderian G. Vospominanija nemeckogo generala [Memories of a German general]. Moscow: Centrpoligraf, 2013. 576 p. (In Russian).

3. Serov I. Zapiski iz chemodana [Scraps from a suitcase]. M.: Prosveshhenie, 2016. 688 p. (In Russian).

4. Shirer U. Vzlet $i$ padenie Tret'ego rejha [Rise and fall of the Third Reich]. Vol. 1. Moscow: Politizdat, 1991. 653 p. (In Russian).

5. Jandourek Ja. A esli by v 1938 godu SSSR nam pomog? [Ehat if the USSR helped us in 1938?] URL: http://inosmi.ru/ politic/20161004/237963267.html (accessed: 19.11.2016) (In Russian).

6. Berlin Alert. The Memoirs and Reports of Truman Smith, Hassen - Stanford, 1984.

7. Blum J. From the Morgenthau Diaries. The Years of Crisis, 1928 - 1938. Boston: Houghton Mifflin Company, 1959. $583 \mathrm{p}$.

8. Clark C. The Slleepwalkers. How Europe
Went to War in 1914. London: Penguin, 2012. 607 p.

9. Hearden P. Roosevelt Confronts Hitler. America's Entry into World War II. Decalb: Northern Illinois University Press, 1987.340 p.

10. Hibbert C. Benito Mussolini. The Rise and Fall of il Duce. London: Penguin Books, $1962.340 \mathrm{p}$.

11. Lamb R. The Ghosts of Peace. 1935 - 1945. Wilton, 1987. 353 p.

12. Murray W. The Change in the European Balance of Power, 1938 - 1939. The Path to Ruin. Princeton: Princeton University Press, 1984. 494 p.

13. Pillar P.R. The Age of Nationalism. The National Interest. September - October, 2013. URL: http://nationalinterest.org/ article/the-age-nationalism-8954 (accessed: 19.11.2016)

14. Posen B. The Sources of Military Doctrine. France, Britain and Germany Between the World Wars. Ithaca: Cornel University Press, 1984. 283 p.

15. Rees L. The Dark Charisma of Adolf Hitler. Leading Millions into the Abyss. London: Ebury Press, 2013. 480 p.

16. Speer A. Inside the Third Reich. New York: Avon, 1970. 596 p.

\section{About the author:}

Alexander Yu. Borisov - Doctor of Historical Sciences, Professor of the MGIMO-University. Extraordinary and Plenipotentiary Envoy of the II class. E-mail: albor@rambler.ru. 